\title{
An approach to convivial urban spaces: a comparison between users' and experts' perception of convivial urban spaces
}

\author{
Mona Y. Shedid ${ }^{*}$ (D) and Noha H. Hefnawy
}

\author{
*Correspondence: monashedid@ \\ bhit.bu.edu.eg \\ Department of Architecture, Faculty \\ of Engineering-Benha, Benha \\ University, Benha, Egypt
}

\begin{abstract}
Convivial urban spaces are a process as well as a philosophy. They revolve around observing users in specific urban spaces to comprehend their various needs, especially their social needs. Designing urban spaces for people to promote social connections is the foundation of creating convivial urban spaces. This means that this form of urban space has been interpreted as a daily social activity and as social pleasure expressed in the physical and psychological context of people's urban space. To provide a convivial environment for all users, effective convivial urban spaces should fulfill certain important aspects. From this point of view, the paper aims to identify the main aspects of creating convivial urban spaces through their repletion in the different theories. Then, the paper will evaluate and arrange the importance of the different aspects that form convivial urban spaces from the users and experts (urban designer and architects) point of view to reach the main objective of the paper which is to create a prospected framework for the urban designer and architects to help them in future decisions in designing convivial urban spaces that fulfill users' needs.

Keywords: Conviviality, Convivial urban spaces, Users' and experts' perception, Social aspects, Quality of urban environment
\end{abstract}

\section{Introduction}

Every day, urban spaces seek a variety of services that people need to enjoy their urban environments in their daily lives. Since urban areas are specifically designed to encourage physical activity and social interaction, any abruption between users and their built environment will result in ineffective urban spaces that fail to meet users' social needs. As a result, this rapid rate of urbanization must be effectively managed to improve the quality of urban spaces to meet user physical and social needs. Conviviality is a concept that is commonly used in sociology, but it is less commonly used in urban design and architecture [1]. Various scholars of urban space have identified a lack of interaction [2], absence of life in the streets [3], loss of social capital, and diminishing equity in public spaces [4].

(c) The Author(s). 2021 Open Access This article is licensed under a Creative Commons Attribution 4.0 International License, which permits use, sharing, adaptation, distribution and reproduction in any medium or format, as long as you give appropriate credit to the original author(s) and the source, provide a link to the Creative Commons licence, and indicate if changes were made. The images or other third party material in this article are included in the article's Creative Commons licence, unless indicated otherwise in a credit line to the material. If material is not included in the article's Creative Commons licence and your intended use is not permitted by statutory regulation or exceeds the permitted use, you will need to obtain permission directly from the copyright holder. To view a copy of this licence, visit http://creativecommons.org/licenses/by/4.0/. The Creative Commons Public Domain Dedication waiver (http://creativecommons.org/publicdomain/zero/1.0/) applies to the data made available in this article, unless otherwise stated in a credit line to the data. 
According to a literature review, conviviality is linked to two characteristics: "livability" and "sociability," which are often used in urban studies and public realm research to characterize public spaces that encourage quality social interaction. Due to the presence of other people in the space, convivial urban space makes pedestrians feel secure and welcome.

The paper will focus on illustrating the ter "conviviality" and study the different social aspects of creating a convivial urban space that satisfies human needs.

The main interest of this study is to find out the main aspects that affect the quality and design of the convivial urban spaces to help architects and urban designers in the future design of urban spaces, as shown in Fig. 1.

To reach the research objectives, the paper will go through two main phases:

Phase (1): Theoretical study:

- Literature and theoretical fundamentals of convivial urban spaces have been reviewed through the various concepts and theorists.

- Identify the concept of conviviality, main concepts, and aspects that create convivial urban spaces.

Phase (2): Empirical study:

- Evaluate the aspects according to their importance to make urban spaces more convivial for the users and experts (urban designers and architects).

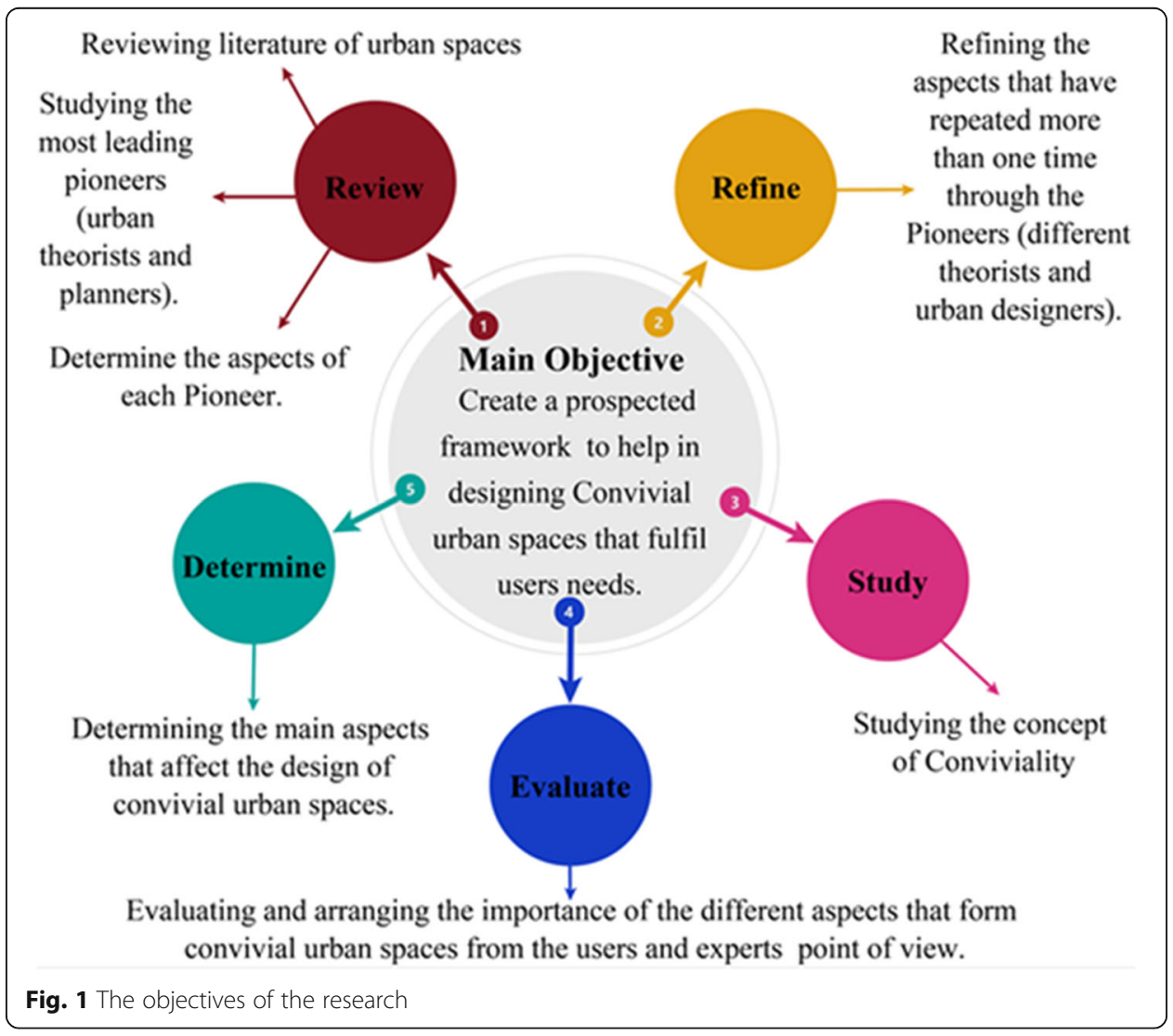


- Arrange the importance of the selected aspects through a questionnaire which is distributed to a group of users and experts (urban designers and architects).

Through the outputs of the first and second phase of the research methodology, the paper will conclude prospected framework for the urban designers and architects to help in designing convivial urban spaces that fulfill users' needs. Finally, the paper attempts to reach a process for designing this type of urban space.

\section{The perception of conviviality}

The term "conviviality" derives from the Latin word "convivium," meaning "to live together" [5].

Conviviality is a common term among philosophers worldwide. It emerges as a critical social and cultural requirement to ensure that everyone has a place in the public realm where their participation is valued [6]. Convivial approaches focus on people's daily lives, where free time, free space, convivial technology, and organization are a social capital derived from cultural networks rather than existential resources like such as income [7]. On the level of urban spaces, urbanists accepted that conviviality is linked to people's everyday social interactions in urban life; it is about creating a welcoming urban space that is built for and with people to make them feel more welcome and happier in their daily life itinerary [8].

\section{Picturing convivial concepts in modern urban theories}

Recently in the twentieth century, many urban theories have emerged to aid in improving the quality of urban life and enhancing people's everyday lives, such as [8, 9]:

1. Smart growth.

2. Urban village.

3. New urbanism.

4. Principles of intelligent urbanism.

Urban conviviality can be accomplished by architecture and society working within those hierarchies to create socially friendly relationships between users. Such hierarchies can be created by the regulation of social levels, with each level occupying an equal physical location in the dominion structure [8].

\section{The profit of creating convivial urban spaces}

Convivial urban spaces influence people by providing a variety of environmental benefits. The following are some of the advantages of creating convivial urban spaces $[8$, 10], as shown in Fig. 2.

\section{Common aspects of creating convivial urban spaces}

Conviviality has been described as an everyday social behavior that is influenced by the physical and psychological context of the user's urban environment. To foster a convivial environment for all users, effective convivial urban spaces must meet certain criteria. The different aspects that form convivial urban spaces were based on reviewing the 


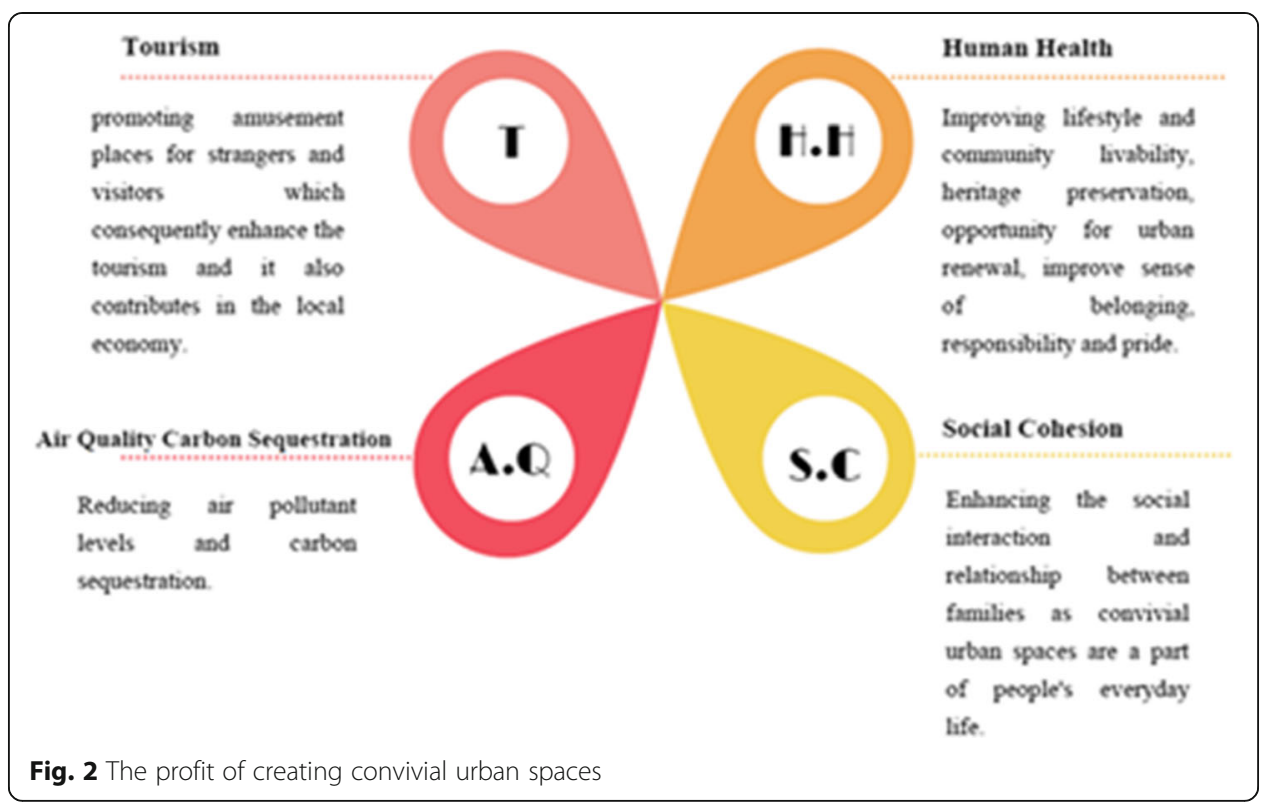

literature of conviviality of urban spaces in books, scientific journals, research projects, and websites [11]. These aspects were obtained through their frequency in the various concepts and theorist studied in the first part [12-19]. They are classified as follows in Table 1.

\section{Methods}

The research study was divided into three phases as follows, as shown in Fig. 3.

\section{The first phase}

The first introductory phase is based on reviewing literature and theoretical fundamentals of the main theorists who dealt with the concepts of urban spaces as a convivial urban environment. These theorists are Jan Gehl, Jane Jacobs, Vikas Mehta, Wiedenhoeft, Kevin Lynch, and Project for Public Space, Allan Jacobs, and Jacobs \& Appleyard.

The paper surveyed eight of these theorists to study the main aspects forming convivial urban spaces. Finally, a table is created with the most important aspects that form convivial urban spaces through the frequency of these aspects (that repeated more than one time) in the different theorist and urban planners that have been studied, as shown in Table 2.

\section{The second phase}

In the second phase, the importance of the selected aspects is evaluated and arranged through an online questionnaire which distributes to a group of experts and users to figure out the main aspects and their importance to each other that form convivial urban spaces. 
Table 1 Aspects of creating convivial urban spaces. Source: Authors based on [12-19]

\begin{tabular}{|c|c|c|c|c|c|c|c|c|}
\hline & \multicolumn{8}{|c|}{ Theorists and Urban Planners } \\
\hline & Jan Gehl| & Jane Jacobs & Vikas Mehta & Wiedenhoeft & Kevin Lynch & $\begin{array}{l}\text { Project for } \\
\text { Public Space }\end{array}$ & Allan Jacobs & $\begin{array}{l}\text { Jacobs \& } \\
\text { Appleyard }\end{array}$ \\
\hline & Geh1, (2010) & Jacobs, (1961) & Mehta, (2008) & Wiedenhoeft, (1981) & Lynch, K. (1960) & $\begin{array}{c}\text { Project for } \\
\text { Public Space, } \\
(2000)\end{array}$ & $\mathrm{Jacobs}_{2}(1993)$ & $\begin{array}{l}\text { Jacobs \& } \\
\text { Appleyard } \\
\text { (1987) }\end{array}$ \\
\hline \multirow{12}{*}{ "艹 } & Safety \& Security & Safety & Safety & Sense of Containment & Control & & Safe & $\begin{array}{l}\text { Identity \& } \\
\text { Control }\end{array}$ \\
\hline & Accessibility & Small Blocks & $\begin{array}{l}\text { Feasibility and } \\
\text { accessibility }\end{array}$ & & Access & $\begin{array}{l}\text { Access and } \\
\text { linkages }\end{array}$ & Accessible & Justice \\
\hline & $\begin{array}{l}\text { Interesting façades } \\
\text { \& views at eye } \\
\text { level }\end{array}$ & Aged buildings & $\begin{array}{l}\text { Sense of belonging: } \\
\text { community places }\end{array}$ & Sense of Place & Sense of place & & Memorable & livability \\
\hline & $\begin{array}{l}\text { Edge effect/ } \\
\text { attractive zones for } \\
\text { standing/staying }\end{array}$ & $\begin{array}{c}\text { Adequate } \\
\text { Concentration of } \\
\text { Buildings }\end{array}$ & Sensory pleasure & $\begin{array}{l}\text { Employment of } \\
\text { Elevation Changes }\end{array}$ & & & $\begin{array}{l}\text { Have Local } \\
\text { Meaning for the } \\
\text { Community }\end{array}$ & $\begin{array}{l}\text { Authenticity } \\
\text { and meaning }\end{array}$ \\
\hline & $\begin{array}{l}\text { Lighting \& Good } \\
\text { places to sit }\end{array}$ & & $\begin{array}{l}\text { Comfort: } \\
\text { environmental and } \\
\text { physical }\end{array}$ & Sufficient Places to Sit & & $\begin{array}{l}\text { Comfort and } \\
\text { image }\end{array}$ & $\begin{array}{l}\text { Comfortable and } \\
\text { Pleasant }\end{array}$ & $\begin{array}{l}\text { Access to } \\
\text { opportunity, } \\
\text { imagination, } \\
\text { and ioy }\end{array}$ \\
\hline & $\begin{array}{l}\text { Street furniture } \\
\text { that provides } \\
\text { "talkscapes" }\end{array}$ & & Usefulness & $\begin{array}{l}\text { Materials and Textures } \\
\text { of Aesthetic Quality }\end{array}$ & $\begin{array}{l}\text { The } \\
\text { appropriateness } \\
\text { and adaptability of } \\
\text { urban form }\end{array}$ & & $\begin{array}{l}\text { Aesthetic } \\
\text { Quality }\end{array}$ & Self-Reliance \\
\hline & Scale & Scale & & & & & & \\
\hline & $\begin{array}{l}\text { Social Activities } \\
\text { and interaction }\end{array}$ & $\begin{array}{l}\text { Assimilating } \\
\text { Children }\end{array}$ & & $\begin{array}{l}\text { Places to Perform } \\
\text { Human Activities }\end{array}$ & Vitality & Sociability & $\begin{array}{c}\text { Social } \\
\text { Interaction }\end{array}$ & $\begin{array}{c}\text { Open } \\
\text { communities } \\
\text { and public life }\end{array}$ \\
\hline & $\begin{array}{l}\text { Diversity in } \\
\text { Activities }\end{array}$ & $\begin{array}{l}\text { Diversity\& } \\
\text { Mixed Uses }\end{array}$ & & $\begin{array}{l}\text { Shops and A Source of } \\
\text { Food and Drink }\end{array}$ & & $\begin{array}{l}\text { Uses and } \\
\text { activity }\end{array}$ & Diversity & \\
\hline & Weather & & & $\begin{array}{l}\text { Introduction of Plant } \\
\text { and Water Elements }\end{array}$ & & & & \\
\hline & Recognizability & Contact & & Recognizability & & & & \\
\hline & $\begin{array}{l}\text { Integrated } \\
\text { transportation }\end{array}$ & & & $\begin{array}{l}\text { Separation of Traffic } \\
\text { from Urban Spaces }\end{array}$ & & & & \\
\hline
\end{tabular}

\section{Participants}

The population sample maintained under the analysis should be chosen to infer statistically relevant generalizations about a specific feature of this population to preserve the research sample's representativeness. Each questionnaire has been conducted during a 3-week period to a group of 50 participants with different characteristics.

\section{Stimuli}

The empirical study is based on two online questionnaires (one for the users, and the other one for the expert), where the main goal is evaluating and arranging the different aspects forming convivial urban spaces according to their importance to make them

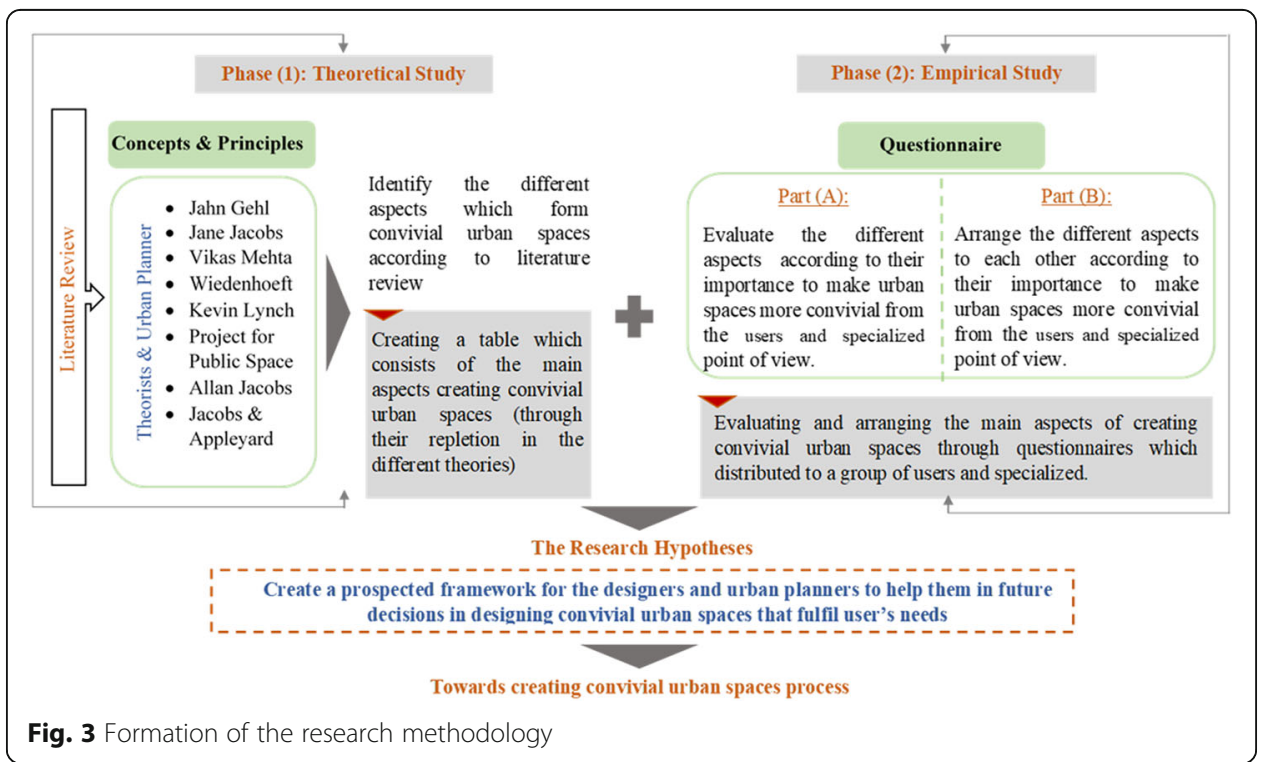


Table 2 Identifying the main aspects of creating convivial urban spaces through their repletion in the different theories. Source: Authors based on [12-19]

\begin{tabular}{lll}
\hline Theorist and Urban Planner & Main aspects & $\begin{array}{l}\text { Frequency of the } \\
\text { aspects }\end{array}$ \\
\hline Gehl, Jacobs, Mehta, Allan Jacobs & 4 \\
Gehl, Mehta, Project for Public Space, Allan Jacobs & Safety \& security & 4 \\
Gehl, Wiedenhoeft, Project for Public Space, Allan & $\begin{array}{l}\text { Social activities and } \\
\text { interaction }\end{array}$ & 4 \\
Jacobs & Diversity in activities & 4 \\
Gehl, Jacobs, Project for Public Space, Allan Jacobs & Surrounding buildings & 4 \\
Gehl, Jacobs, Wiedenhoeft, Lynch & Sense of place & 3 \\
Mehta, Wiedenhoeft, Lynch & Comfort & 3 \\
Mehta, Project for Public Space, Allan Jacobs & Livability \& vitality & 2 \\
Lynch, Jacobs \& Appleyard & Edge effect & 2 \\
Gehl, Jacobs & Sufficient places to sit & 2 \\
Gehl, Wiedenhoeft & Scale & 2 \\
Gehl, Jacobs & Recognizability & 2 \\
Gehl, Wiedenhoeft & Aesthetic quality & 2 \\
Wiedenhoeft, Allan Jacobs & Authenticity \& meaning & 2 \\
Allan Jacobs, Jacobs \& Appleyard & Control & 2 \\
Jacobs \& Appleyard, Lynch & & \\
\hline
\end{tabular}

more convivial from the urban designer and citizen's point of view. To attain this objective, the design of the questionnaires' previous literature review must be put into consideration. Each questionnaire deals with three sections.

The first one was about the participants' age, gender, and job.

The second one is a rating scale question which was used to evaluate the different aspects of creating convivial urban spaces (namely safety \& security, accessibility, social activities and interaction, diversity in activities, surrounding buildings, sense of place, comfort, livability \& vitality, edge effect, sufficient places to sit, scale, recognizability, aesthetic quality, authenticity \& meaning, and control).

The third one is a rating scale question which was used to arrange the different aspects according to their importance to each other, to make urban spaces more convivial.

\section{Procedures}

The required data was collected using an online questionnaire method. The questionnaire form had three sections as follows:

The first section: Participants were asked to provide basic details (age, gender, and job) in response to multiple choice (single answer) questions, which enable respondents to choose only one answer from a list using circular radio buttons.

The second section: the participants were asked to answer one question about evaluate the different aspects to each other according to their importance to make urban spaces more convivial. Five-point rating scale questions were used to answer this section, the question displays a scale of answer options from range (1 "the lowest to ratings" to 5 "the highest ratings"). The respondent selects the number that most accurately represents their response. 
The third section: participants were requested to arrange the different aspects according to their importance to make urban spaces more convivial. The participants were asked to rank the aspects using 15-point rating scale questions (1 "the lowest rating" to 15 "the highest rating"). They arranged the main aspects according to scale/rank questions which can be used to ask respondents to rate items on a scale and to rank them to their importance or preference to each other.

\section{Results and discussion}

The SPSS test was used to analyze all the data in the questionnaires, and the results will be discussed in the following parts:

\section{The questionnaire results}

The results and findings of the questionnaire will be illustrated through comparative analysis charts and tables to determine how users and experts arrange and evaluate aspects of convivial urban spaces in their points of view. After analyzing the results of 50 user questionnaire samples and 50 expert questionnaire samples, SPSS was used to find the following results and conclusions.

First section: Table 3 shows the results of participants' basic information.

Second section: the participants evaluate the importance of each of the 15 aspects based on the participants "point of view using 5 points rating scale (from 1 "not at all" to 5 "very much").

From comparing the results of arranging the different aspects for user and expert, the following points can be concluded about the importance of the selected aspects to figure out the main aspects and their importance to each other that form convivial urban spaces according to the questionnaire participants` point of view:

- Both user and expert agreed that the 1st aspect was safety \& security. The expert also chose comfort as the 1st choice.

- The 2nd aspect for users was comfort, on the other side expert's choice was sufficient places to sit.

- Both users and expert agreed that the 3rd aspect was accessibility. It is to be noted that sufficient places to sit were tied to accessibility in the 3rd place in users' choices.

- The 4th aspect for users was aesthetic quality and control, on the other side experts chose livability \& vitality and esthetic quality.

- The previous points can be concluded in Table 4.

Third section: the aspects were arranged according to their importance to each other from the participants' point of view using a 15-points rating scale questions (1 "the lowest rating" to 15 "the highest rating").

Table 3 Descriptive background parameters of the questionnaire. Source: Authors

\begin{tabular}{|c|c|c|c|c|c|c|c|c|c|c|}
\hline \multirow{2}{*}{ 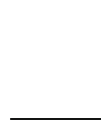 } & \multicolumn{2}{|c|}{ Gender } & \multicolumn{5}{|c|}{ Age group } & \multicolumn{3}{|c|}{ No. of participants } \\
\hline & Male & $\overline{\text { Female }}$ & $\begin{array}{l}20-35 \\
\text { years }\end{array}$ & $\begin{array}{l}36-45 \\
\text { years }\end{array}$ & $\begin{array}{l}46-55 \\
\text { years }\end{array}$ & $\begin{array}{l}55-65 \\
\text { years }\end{array}$ & $\begin{array}{l}\text { More than } 65 \\
\text { years }\end{array}$ & $\begin{array}{l}\text { Total } \\
\text { no. }\end{array}$ & Used & Excluded \\
\hline Experts & $40 \%$ & $60 \%$ & $64 \%$ & $10 \%$ & $12 \%$ & $8 \%$ & $6 \%$ & 50 & 49 & 1 \\
\hline Users & $48 \%$ & $52 \%$ & $54 \%$ & $34 \%$ & $8 \%$ & $2 \%$ & $2 \%$ & 50 & 50 & - \\
\hline
\end{tabular}


Table 4. Arrangement of the 15 aspects according to the importance of each one of them. Source: Authors

\begin{tabular}{|c|c|c|c|c|}
\hline \multicolumn{2}{|l|}{ Experts } & \multirow[t]{2}{*}{ Rank } & \multicolumn{2}{|l|}{ Users } \\
\hline Aspects & Mean & & Aspects & $\overline{\text { Mean }}$ \\
\hline Safety \& security & 4.3 & 1 & Safety \& security & 4.7 \\
\hline \multicolumn{5}{|l|}{ Comfort } \\
\hline Sufficient places to sit & 4.1 & 2 & Comfort & 4.5 \\
\hline \multirow[t]{2}{*}{ Accessibility } & 4.0 & 3 & Accessibility & 4.2 \\
\hline & & & Sufficient places to sit & \\
\hline Esthetic quality & 3.9 & 4 & Esthetic quality & 4.1 \\
\hline Livability \& vitality & & & Control & \\
\hline \multirow[t]{2}{*}{ Social activities and interaction } & 3.8 & 5 & Sense of place & 3.9 \\
\hline & & & Livability \& vitality & \\
\hline \multirow[t]{3}{*}{ Diversity in activities } & 3.7 & 6 & Social activities and interaction & 3.8 \\
\hline & & & Diversity in activities & \\
\hline & & & Scale & \\
\hline \multirow[t]{2}{*}{ Control } & 3.5 & 7 & Recognizability & 3.7 \\
\hline & & & Control & \\
\hline Sense of place & 3.3 & 8 & Edge effect & 3.5 \\
\hline Authenticity \& meaning & & & Surrounding buildings & \\
\hline Scale & 3.1 & 9 & & \\
\hline \multicolumn{5}{|l|}{ Surrounding buildings } \\
\hline Edge effect & 3.0 & 10 & & \\
\hline Recognizability & 2.8 & & & \\
\hline
\end{tabular}

Table 5. Arrangement of the 15 aspects according to the relative importance to each other. Source: Authors

\begin{tabular}{llllll}
\hline Experts & & Rank & & Users & Mean \\
\cline { 5 - 6 } Aspects & Mean & & & Aspects & 13.1 \\
\hline Safety \& security & 12.6 & 1 & & Safety \& security & 10.7 \\
Accessibility & 11.4 & 2 & Accessibility & 10.4 \\
Social activities and interaction & 10.8 & 3 & Comfort & 9.2 \\
Diversity in activities & 10.2 & 4 & Sufficient places to sit & 8.3 \\
Sense of place & 9.8 & 5 & Social activities and interaction & 8.2 \\
Comfort & 9.6 & 6 & Diversity in activities & 8.0 \\
Sufficient places to sit & 8.2 & 7 & & Esthetic quality & 7.4 \\
Edge effect & 7.2 & 8 & & Sense of place & 7.3 \\
Esthetic quality & 6.8 & 9 & Scale & 7.2 \\
Scale & 6.5 & 10 & Control & 6.6 \\
Recognizability & 6.0 & 11 & Authenticity \& meaning & 6.4 \\
Livability \& vitality & 5.7 & 12 & Livability \& vitality & 6.2 \\
Authenticity \& meaning & 5.6 & 13 & Edge effect & 5.6 \\
Control & 5.4 & 14 & Recognizability & 5.5 \\
Surrounding buildings & 4.1 & 15 & Surrounding buildings
\end{tabular}


Table 6 Rotated component matrix. Source: Authors

\begin{tabular}{lllll}
\hline Main aspects & Component & & & \\
\cline { 2 - 5 } & $\mathbf{1}$ & $\mathbf{2}$ & $\mathbf{3}$ & $\mathbf{4}$ \\
\hline Safety \& security & .304 & .066 & .852 & -.105 \\
Accessibility & .112 & .170 & .754 & .126 \\
Social Activities and interaction & .230 & .830 & .108 & .057 \\
Diversity in activities & .164 & .799 & .323 & .090 \\
Sense of place & .667 & .203 & .277 & .168 \\
Comfort & -.001 & .271 & .684 & .429 \\
Edge effect & .710 & .009 & .139 & .384 \\
Sufficient places to sit & .069 & .121 & .475 & .597 \\
Scale & .767 & .130 & .200 & .260 \\
Recognizability & .863 & .076 & .004 & .146 \\
Esthetic quality & .329 & .124 & .115 & .709 \\
Authenticity \& meaning & .341 & .251 & $-.048-$ & .696 \\
Control & .747 & .037 & .182 & -.010 \\
Surrounding buildings & .665 & .398 & -.132 & .169 \\
Livability \& vitality & .014 & .805 & .107 & .301 \\
\hline
\end{tabular}

From analyzing the results of the second part of the questionnaire it has been found that for the expert it is safety and security, and then accessibility and social activities and interaction, but the most important aspect for the users is the safety and security and then comes accessibility and comfort and the least important for them is surrounding buildings. From Table 5, users' and experts' aspects for convivial urban spaces can be ranked as the following:

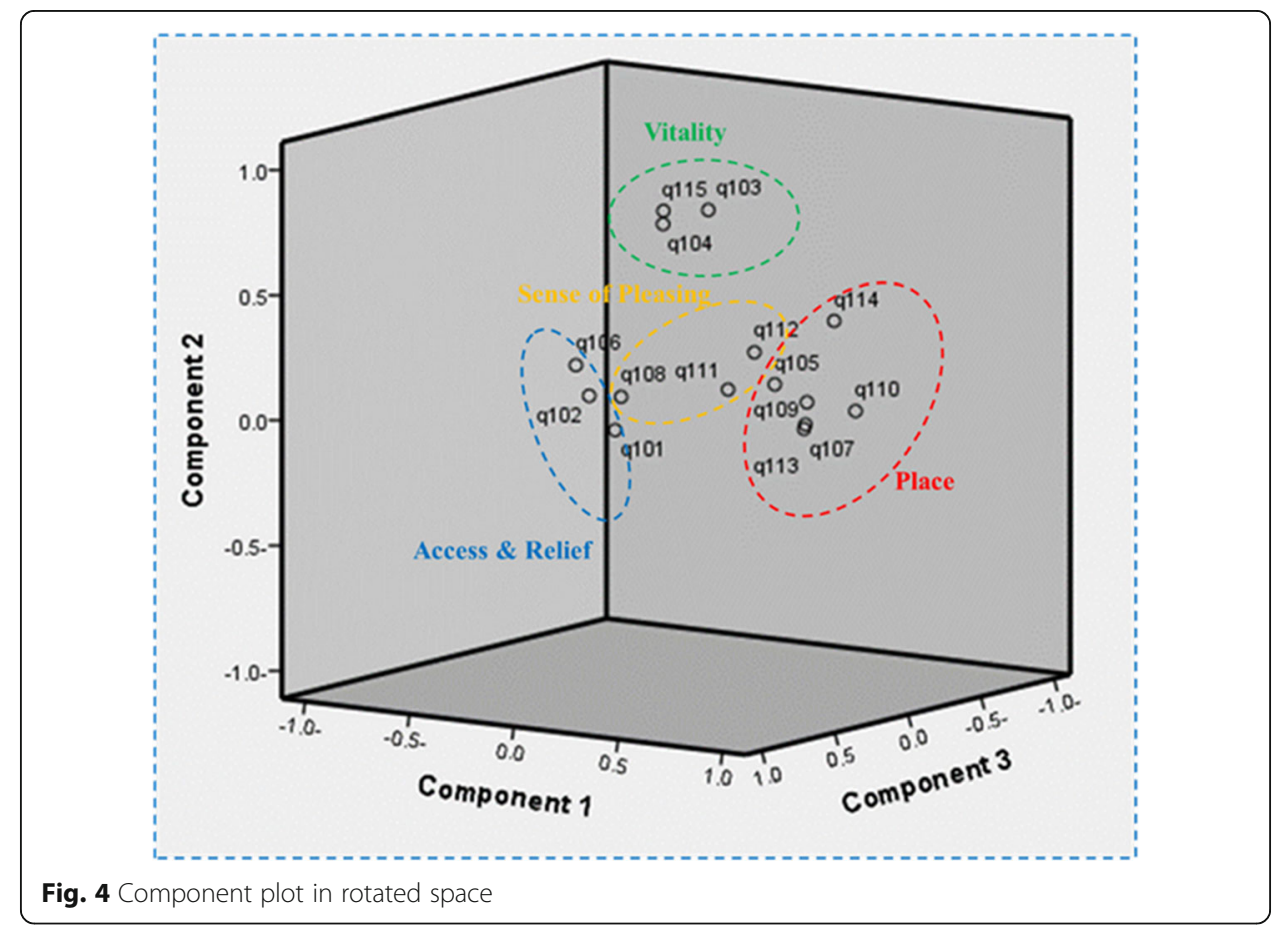




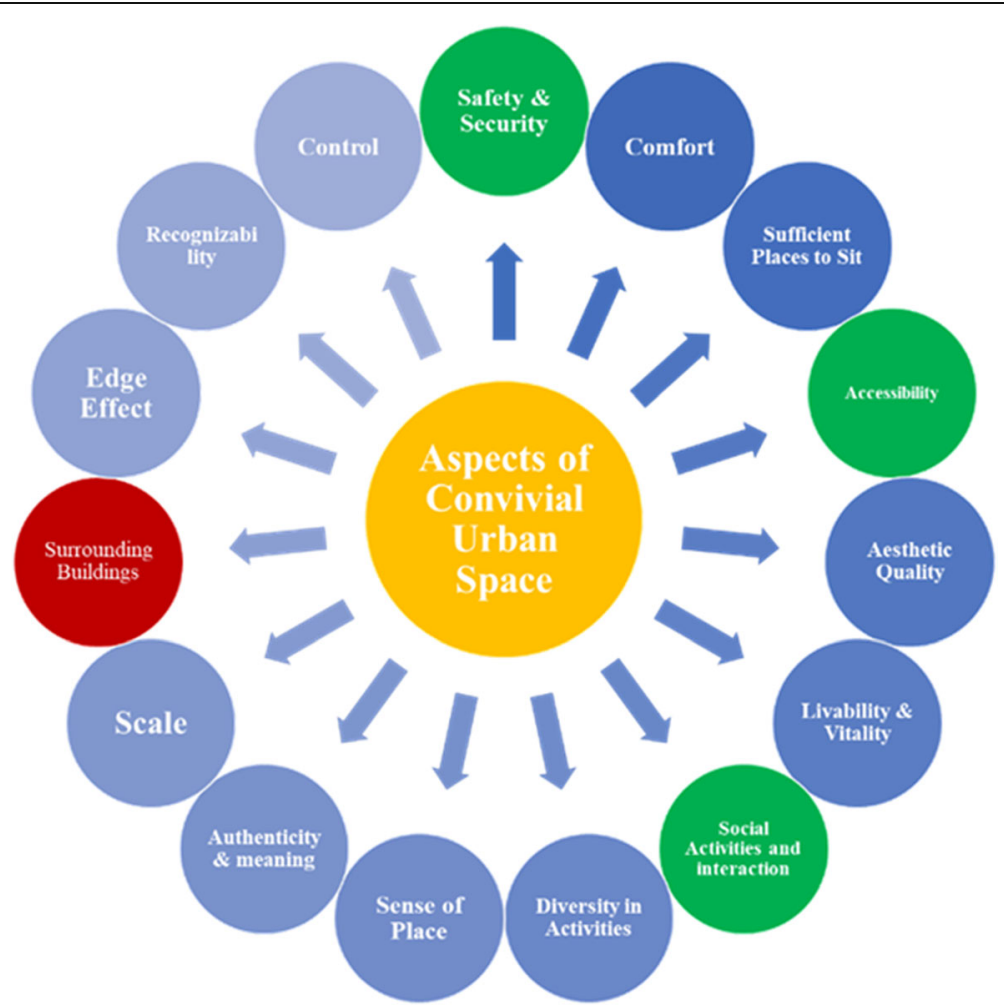

Fig. 5 The main aspects of creating convivial urban spaces

Table 7. The prospected framework of creating convivial urban spaces. Source: Authors based on $[17,21,22]$

\begin{tabular}{|c|c|c|c|}
\hline \multicolumn{2}{|c|}{ Groups } & \multirow[t]{2}{*}{ Aspects } & \multirow[t]{2}{*}{ Significance } \\
\hline No. & Name & & \\
\hline 1 & Place & $\begin{array}{l}\text { Sense of place, edge effect, scale, } \\
\text { recognizability, control, and surrounding } \\
\text { buildings }\end{array}$ & $\begin{array}{l}\text { To create a convivial urban space, the physical } \\
\text { elements must be introduced that would make } \\
\text { people recognize their surrounding } \\
\text { environment through the effective relationship } \\
\text { between the scale and edge effect of the } \\
\text { buildings. } \\
\text { Convivial urban spaces are often envisaged to } \\
\text { transform communities' spaces into lively and } \\
\text { attractive places; to enhance quality of life and } \\
\text { opportunity for existing residents. }\end{array}$ \\
\hline
\end{tabular}

2 Vitality Social activities \&interaction, diversity in activities, and livability \& vitality

3 Access \& Safety \& security, accessibility, and comfort Relief

4 Sense of Sufficient places to sit, esthetic quality, and Pleasing authenticity \& meaning
The different activities are basic elements of a convivial space. They attract users to communicate in different activities and for there to be a livable community and improve the quality of life there.

These spaces should be secured through landscape elements to be a safe and comforting environment. They should be also accessible, and well connected to the surrounded places.

Users are drawn to places that provide them with enough seating options so that they can enjoy the esthetic quality of the space. 


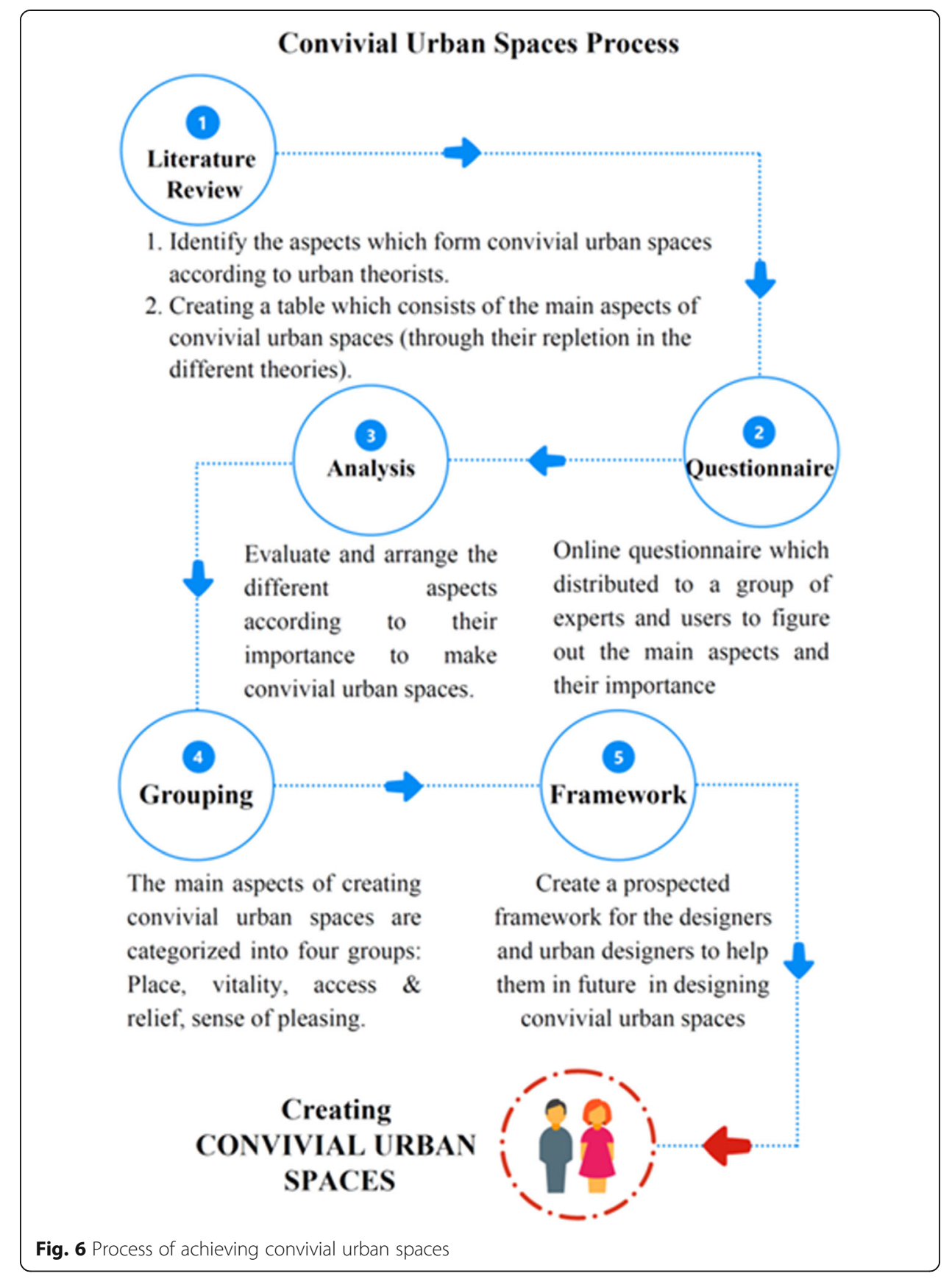

The main aspects of creating convivial urban spaces

A factor analysis method (carried out using SPSS software) was applied to test the main aspects of creating convivial urban spaces and categorizes the aspects into groups.

\section{Procedures}

Principal component analysis was used to synthesize and consolidate the variation trends in those components that are theoretically correlated with the conviviality of urban spaces to validate the questionnaire. PCA is a "commonly used dimensionality reduction tool" that aims to reduce the dimensionality of the 
function space while maintaining as much "input variance (of the initial space) as possible [20].

Varimax (orthogonal rotation) with the Kaiser criterion was used to perform factor rotation. A rotated part matrix and a transformation matrix were the end results. The variables loaded on each factor were indicated by the rotated component matrix, allowing the researchers to come up with new factors. Four components emerged from PCA that clarified the total variance; these components were chosen based on a visual inspection of the scree plots. Table 6 provides the factor loadings of the original variables studied here and the four components generated by the PCA that helps in interpreting these components, while Fig. 4 illustrates the component plot in rotated space for three PCA components including the 4 main groups: where:

Group (1): named Place and consisted of 6 aspects (sense of place, edge effect, scale, recognizability, control, and surrounding buildings).

Group (2): named Vitality composed of 3 items (social activities and interaction, diversity in activities, and livability \& vitality)

Group (3): named Access \& relief consisted of 3 aspects (safety \& security, accessibility, and comfort).

Group (4): named Sense of pleasing consisted of 3 aspects (sufficient places to sit, esthetic quality, and authenticity \& meaning).

\section{Conclusions}

The paper highlights the significant role of convivial urban spaces in increasing the quality of urban life as well as people's social interactions through identifying the main aspects of creating convivial urban spaces.

Through an online questionnaire, a group of experts and users agreed on giving safety and security the highest priority followed by accessibility, whereas the social activities interactions aspect was chosen to be among the top 5 aspects while the surround building aspect was the least priority.

Next, a proposed framework was created based on the theoretical fundamentals and the first phase of the empirical studies in the paper (Fig. 5). It revealed the main aspects and their significance to reach a successful convivial urban space, as shown in Table 7.

The process of achieving convivial urban spaces passes through five stages to help urban designers and architects to design convivial urban spaces, as shown in Fig. 6.

Acknowledgements

Not applicable

\section{Authors' contributions}

Both MS and $\mathrm{NH}$ conceived of the presented idea, developed the theoretical formalism through collecting and analyzing data. They designed and constructed the questionnaire then analyzing the data and results. All authors read and approved the final manuscript.

Availability of data and materials

All relevant data concerning the paper can be supplied by the principal investigator upon request.

\section{Declarations}

Ethics approval and consent to participate

Not applicable

Consent for publication

Not applicable 
Competing interests

The authors declare no competing interest regarding the subject of the study.

Received: 25 June 2021 Accepted: 25 August 2021

Published online: 27 October 2021

\section{References}

1. Ivan I (1973) Tools for conviviality. Harper \& Row, New York

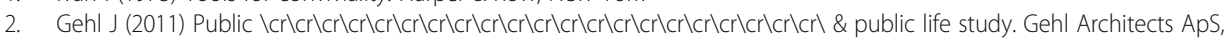
Copenhagen, Denmark

3. La Cecla F, O'Mahony M (2012) Against architecture. Green Arcade/PM Press, San Francisco, Oakland

4. Putnam R, Bowling A (2000) The collapse and revival of American community. Simon \& Schuster, New York

5. Vertovec MN (2014) Comparing conviviality: dreams and realities of living-with-difference. Eur J Cult Stud 17

6. Thombre, L., and Kapshe, C., Conviviality as a spatial planning goal for public open spaces, International Journal of Recent Technology and Engineering (IJRTE) ISSN: 2277-3878, 2020, volume-8 Issue-5.

7. Shorthose J (2002) Conviviality in global cultural development: diversity, freedom, and agency. Int J Dev Stud 45:3

8. Said, H., (2020), appropriating guidelines for a convivial urban space "with special reference to landscape features", faculty of engineering, Cairo university, 2020.

9. Bugadze, N., Theory and practice of "intelligent urbanism", Bulletin of the Georgian National Academy of Sciences, March 2018 vol. 12, no.3.

10. Shafto, H., Convivial urban spaces: creating effective public places, Taylor \& Francis, 2012, retrieved from URL: https:// books.google.com.eg/books?id=oYxfCzYOpNwC, accessed in January 2021.

11. Naghibi E, Habib F, Shabani A (2015) Pedestrian area design to promote social interaction (case study: Isfahan Khajoo neighborhood). Int J Arch Urban Dev:31-42

12. Gehl J (2010) Cities for people. Island Press, Washington, DC

13. Jacobs J (1961) The death, and life of great American cities: the failure of modern town planning. Random House, USA

14. Mehta V (2008) Walkable streets: Pedestrian behavior, perceptions, and attitudes. J Urbanism:217-245. https://doi.org/1 $0.1080 / 17549170802529480$

15. Wiedenhoeft R (1981) Cities for people: practical measures for improving urban environments. Van Nostrand Reinhold, New York

16. Lynch K (1960) The Image of the City. M.IT Press, USA, Massachusetts

17. Project for Public Spaces (2000) How to turn a place around: a handbook of creating successful public spaces. Project for Public Space, New York

18. Jacobs AB (1993) Great Streets. MIT Press, USA

19. Jacobs A, Appleyard D (1987) Toward an urban design manifesto. Journal of the American Planning Association 53(1): 112-120. https://doi.org/10.1080/01944368708976642

20. Giannakopoulos, T., and Pikrakis, A., Introduction to Audio Analysis: Music Information Retrieval, Academic Press, 2014, ch.8, pp. 211-231.

21. Project for Public Spaces, (2016), Placemaking: What if we Built our Cities Around Places?, retrieved from URL: https:// issuu.com/projectforpublicspaces/docs/oct_2016_placemaking_booklet, accessed July 2021.

22. Helmy, M. (2020), "Placemaking in Arab Cities. Realities, challenges, and prospects", The Journal of Public Space, 5(1), pp. 1-4. doi: retrieved from URL: https://www.journalpublicspace.org/index.php/jps/article/view/1247, accessed in July 2021.

\section{Publisher's Note}

Springer Nature remains neutral with regard to jurisdictional claims in published maps and institutional affiliations.

\section{Submit your manuscript to a SpringerOpen ${ }^{\circ}$ journal and benefit from:}

- Convenient online submission

- Rigorous peer review

- Open access: articles freely available online

- High visibility within the field

- Retaining the copyright to your article

Submit your next manuscript at $\boldsymbol{\Delta}$ springeropen.com 